\title{
Kom ons stem: Wat het Jesus regtig gesê?
}

\author{
J Botha \\ Potchefstroomse Universiteit vir $\mathrm{CHO}$
}

\begin{abstract}
Let us vote: What did Jesus really say?

Since 1985 the study of the Jesus tradition has taken interesting new directions in the USA. A Jesus Seminar was initiated by the well-known RW Funk and some other leading American New Testament scholars. The question of what Jesus himself really said and what was attributed to him by tradition during later stages, was tackled anew with the explicit additional aim of 'popularizing' the results of this research. Since its inception the Jesus Seminar has grown into an academic institute, Westar Institute, with a whole range of research activities. In addition to this, a new publishing house for biblical and related subjects, Polebridge Press, was launched. In this article all these developments are discussed, with special attention to the Jesus Seminar. Finally, by applying the philosophical concepts of 'exigence' and 'rhetorical situation, the article gives a possible 'explanation' for these new stimuli in some circles of American biblical scholarship.
\end{abstract}

Die rolprent 'The last temptation of Christ' het in die verlede heelwat aandag in die openbare media gekry (vgl o a Olivier 1988: 24-26; Ostling 1988: 69-74). Hierdeur is die eeue-oue vraag, naamlik 'Wie was Jesus?' weer opnuut op die voorgrond gebring. Die antwoord op hierdie vraag is alles behalwe voor die hand liggend. Soos een persberig dit gestel het: 'The debate among scholars is as heated as the one in Hollywood' (Ostling 1988: 69). In die VSA is daar reeds die afgelope drie jaar 'n groep akademici aan die werk wat opnuut weer en op 'n nuwe manier probeer om ' $n$ antwoord te vind op hierdie vraag.

Tydens 'n kongres van die Westar Institute te Sonoma, Kalifornië in 1988, is gestem oor 'wat Jesus regtig gesê het'. Die vraag word met groot erns gevra deur 'n 
groep van die VSA se knapste akademici onder leiding van die bekende professor Robert W Funk. Hulle stem oor die outentisiteit van uitsprake wat in die Evangelies aan Jesus toegeskryf word.

Die doel van hierdie artikel is nie om 'n nuwe bydrae tot die navorsing in die Jesustradisie te probeer lewer nie. Die gedagte is eerder om 'n bekendstelling van hierdie belangrike ontwikkeling in die kontemporêre Amerikaanse Bybelwetenskap te doen - iets wat miskien tot dusver nog nie so bekend binne Afrikaanse teologiese leserskringe is nie.

Die geskiedenis van die Westar Institute is tot 'n groot mate die geskiedenis van Robert W Funk en daarom in die eerste plek een en ander oor sy loopbaan.

\section{ROBERT W FUNK, WESTAR INSTITUTE EN POLEBRIDGE PRESS}

Meeste predikante en teoloë is goed bekend met die naam RW Funk. Hy het sy bekendheid veral te danke aan sy Engelse vertaling en uitbreiding van die standaard Griekse grammatika van die Nuwe Testament, die grammatika van Blass en DeBrunner, A Greek grammar of the New Testament and other early Christian literature. Dit is in 1961 deur Chicago University Press gepubliseer. Sy boek Language, hermeneutic and word of God (1966), latere publikasies soos Jesus as precursor (1975) en Parables and presence: Forms of the New Testament tradition (1982) en sy redakteurskap van Fortress Press se reeks Foundations and facets, met onder andere die New Gospel Parallels (1985) in die reeks (om maar net enkele van die bekendstes te noem), het hom gevestig as een van die invloedrykste Nuwe Testamentici van die tweede helfte van die twintigste eeu.

Funk het in 1953 aan die Vanderbilt University gepromoveer en het in Nuwe Testament doseer by verskeie bekende Amerikaanse Universiteite tot en met sy aftrede in 1986. Die laaste paar jaar voor sy aftrede was hy verbonde aan die Universiteit van Montana.

Gedurende sy loopbaan het hy op die besture van verskeie belangrike verenigings en instellings (soos byvoorbeeld die American Council of Learned Societies, die American Academy of Religion (AAR), die Society of Biblical Literature (SBL), die Council on the Study of Religion) gedien en deurgaans 'n baie groot invloed uitgeoefen. As stigter en eerste redakteur van die tydskrif Semeia: An experimental Journal for Biblical Criticism (1974) het hy 'n groot rol gespeel in die totstandkoming van een van die belangrikste vaktydskrifte in die Bybelwetenskap vandag. Hy dien ook op die redaksie van die Hermeneia-kommentaarreeks en het verskeie van die oorspronklike Duitse uitgawes in dié reeks in Engels vertaal. 
Funk is 'n merkwaardige mens: charismaties, briljant, met 'n ongelooflike dryf$k r a g$ en inisiatief om mense te inspireer en om ' $n$ wye verskeidenheid van nuwe dinge aan te pak en deur te voer. En hy is heel omstrede. In die woorde van James Hester (1988: 3): 'Bob Funk ... is filled with a fire in his bones to revolutionize the scholarly enterprise of biblical study'. Hierdie drang om nuwe deure oop te maak in die Bybelwetenskap en om nuwe grense oor te steek, is sekerlik die vernaamste deurlopende kenmerk in al sy akademiese en verwante bedrywighede. Hy beskou homself as 'n pionier. In die laat sestigerjare was hy een van die jong Turke wat 'n paleisrewolusie in die SBL gelei het om die beheer van die liggaam te bevry uit die hande van die (volgens hulle) 'gevestigde, stagnante, stedelike, Europeesgeoriënteerde Ooskus-establishment'. In die ses jaar wat Funk Uitvoerende Sekretaris van die SBL was (1968-1973) het hy geweldig baie verrig. In 1972 het hy byvoorbeeld ' $n$ internasionale kongres van vakverenigings in die gebied van godsdiens/religie in Los Angeles georganiseer wat die aandag van die openbare pers sowel as protesgroepe (soos 'Jews for Jesus') getrek het. In 1975 was hy president van die SBL.

Die kroonjuweel van sy kreatiewe genialiteit was egter die totstandkoming van Scholars Press. Hy het dit gestig om die groeiende publikasie-aktiwiteite van verskeie vakverenigings te koördineer. Scholars Press was meer as 'n uitgewery. Dit was ' $n$ instelling wat die akademie gedien het deur ook verskillende ander dienste te verskaf, soos byvoorbeeld die druk van bulletins en die organisasie van jaarvergaderings. Heelwat van die proefskrifte van Funk se doktorale studente is deur Scholars Press gepubliseer (o a John L White se The form and function of the body of the Greek letter, 1972, en Chan Hie Kim se The familiar letter of recommendation, 1972). Ander bekende doktorale studente van Funk is onder meer WG Doty en Carin King. Die lesinglokaal en die normale akademiese uitdrukkingsmedia is deur Scholars Press vervang as die plek waar hy sy navorsing kon doen en die resultate kon aanbied. Mettertyd het daar egter kritiek gekom teen sy hantering van Scholars Press en uiteindelik het die direksie hom in 1979 afgedank. Vir die eerste keer in meer as 'n dekade was hy toe sonder 'n medium waardeur hy sy visie en energie kon kanaliseer. Hy kon egter nie meer sonder so iets funksioneer nie. In 1981 stig hy 'n nuwe uitgewery, Polebridge Press en in Oktober 1984 roep hy die eerste beplanningsvergadering van die Jesus Seminar byeen. Nadat hy in 1986 afgetree het as professor by die Universiteit van Montana, het hy ' $n$ instituut in die lewe geroep om ' $n$ wye verskeidenheid van navorsingsprojekte te loods en te koördineer, naamlik die Westar Institute.

Eg Amerikaans word die instituut onder 'n slagspreuk bemark: 'Westar Institute - an explosion of research activities'. Hulle is tans besig met 'n intensiewe 
ledewerwingsveldtog. Die Westar Institute word allerweë beskou as 'n konkurrent vir die gevestigde Society of Biblical Literature. Funk het daarin geslaag om 'n groot groep van die VSA se knapste Bybelwetenskaplikes (en ook mense uit ander dissiplines soos sosiologie, literatuurwetenskap en filosofie) rondom hom te versamel. Alan Culpepper (outeur van The anatomy of the Fourth Gospel) was byvoorbeeld tydens die Sonoma-kongres voorsitter van die Jesus-seminaar. Enkele ander prominente name onder die deelnemers is William A Beardslee, JD Crossan, Howard C Kee, Werner H Kelber, Burton L Mack, John H Elliott, Robert T Fortna, Walter Wink, Bruce Malina en Vernon K Robbins. Weer eens eg Amerikaans (met hulle kenmerkende aandrang op vryheid van assosiasie en vryheid van spraak), is meeste van hierdie akademici óok lede van die SBL en/of die CBA. Hulle betrokkenheid by Westar weerhou hulle dus nie van betrokkenheid by die ouer en meer gevestigde vakverenigings nie. Westar self word egter tot 'n groot mate oorheers deur die presence van Robert Funk - al kom hy op die oog af voor as 'n besadigde en rustige mens wat met 'n sagte stem praat en homself nie op 'n geselskap afdwing nie.

Die formele doelstellings van die Westar Institute (soos gestel in ' $n$ inligtingsbrosjure) is 'to overcome (i) the insulation and isolation of academic research from popular culture, (ii) an uninformed public; (iii) the unreflective defense of established methodologies and (iv) the segregation of the disciplines from each other'. Die tweede doelstelling is grootliks gemik teen die fundamentalisme in die VSA en die derde teen die SBL. Om hierdie doelstellings te bereik reël die instituut seminare en halfjaarlikse ledevergaderings, publiseer Foundations \& Facets Forum ('n wetenskaplike tydskrif), die Westar Magazine ('n meer populêre tydskrif) en boeke en reekse deur Polebridge Press. So byvoorbeeld is die reeks Foundations \& Facets deur Polebridge Press by Fortress Press oorgeneem en is hulle besig met 'n hele klomp nuwe reekse. Die doel met hierdie reekse is om nuwe navorsingsinstrumente tot beskikking van Bybelwetenskaplikes te stel, om basiese versamelings van onverwerkte data te verskaf, nuwe uitgawes en vertalings van klassieke Westerse tekste te publiseer, om ensiklopedië van kennis en akademiese resultate beskikbaar te stel asook woordeboeke van tale, sosiale waardes en tegniese terme.

Tans organiseer en ondersteun die instituut ses seminare. Die 'Bible, Narrative \& American Culture'-seminar bestudeer die verhale en simbole wat die Amerikaanse lewe en denke gevorm het. Hulle is tans besig met 'n studie van die funksie van die Pasga en die Lydensverhaal van Jesus in 'civil religion' en in geweld. IHierdie groep bestudeer onder andere tans die moontlike parallelle tussen die Romeinse onderdrukking van dele van die bevolking en die moderne Amerikaanse verskynsel van letterlik honderde duisende daklose mense in 'n welvarende moderne land. 
Die 'Literary Facets'-seminaar bestudeer die literêre dimensies van antieke en moderne religieuse en filosofiese tekste met die doel om 'n ensiklopedie van literêre fasette saam te stel asook 'n narratiewe kommentaarreeks op die Bybel. Roberts C Tannehill (outeur van The narrative unity of Luke-Acts) is tans die leier van hierdie seminaar.

Die 'Social Facets'-seminaar bestudeer die sosiale kontekste en kulturele bedrywighede - religieus, eties en polities - van verskeie bewegings uit die vroegChristelike era. Hulle doel is om 'n ensiklopedie van sosiale fasette, ' $n$ woordeboek van sosiale waardes asook 'n reeks handboeke te publiseer. Leidende figure in hierdie seminaar is mense soos Bruce M Malina, Jerome H Neyrey, John H Elliott en Douglas Oakman. Persoonlik meen ek dat hierdie spesifieke navorsingsgroep in die toekoms baie groot invloed sal uitoefen. Hernieude belangstelling in die sosiohistoriese sowel as die sosiologiese fasette van die Nuwe-Testamentiese wèreld, staan op die oomblik in die brandpunt van die Nuwe-Testamentiese wetenskap. Laastens het Westar ook nog 'n 'Hebrew Bible Seminar' en 'n 'Seminar on Greek Grammar and Lexicography.' (Benewens hierdie seminaar van die Westar Institute is daar tans ook ten minste drie ander belangrike navorsingsgroepe in die VSA wat besondere aandag gee aan die sosiale aspekte van die vroeë Christendom, vgl Hollenbach 1989: 13-14).

Laasgenoemde groep het tydens die Sonoma-byeenkoms bespreking gevoer oor wat hulle te doen staan in verband met 'n moontlike heruitgawe van die Blass/ DeBrunner/Funk-grammatika van die Nuwe Testament. 'n Nuwe Duitse uitgawe, hersien en uitgebrei deur Rehkopf, is in 1979 in Göttingen, Wes-Duitsland, gepubliseer (Grammatik des neutestamentlichen Griechisch). Chicago University Press wil hê Funk moet dít nou weer in Engels vertaal. Aangesien hy dit in 1961 met 'n vroeëre uitgawe van die grammatikaboek gedoen het, het hy die eerste reg op so 'n onderneming. Indien hy dit nie doen nie, beplan Chicago University Press om iemand anders te vra om dit te doen. Aangesien dit allerweë as een van die standaard Griekse grammatikas op die Nuwe Testament beskou word, wil Funk nie graag sy greep daarop verloor nie. Hy voel egter dat, in die lig van die geweldige ontwikkeling in die moderne linguistiek sedert die sestigerjare, die hele grammatika grondig herskryf moet word en nie net hersien en effens uitgebrei kan word soos Rehkopf gedoen het nie. Die grammatika het egter 'n geskiedenis wat terug strek tot in die vorige eeu toe Blass daaraan begin werk het. Om nou 'n grondige nuwe en volledige grammatika saam te stel, is dus nie ' $n$ dag se werk nie. Funk self is so bedrywig met verskeie ander projekte, ten spyte van die feit dat hy reeds in sy middel sestigerjare is, dat hy self nie nou so ' $n$ groot projek alleen kan aanpak nie. Uit die bespreking te Sonoma het dit geblyk dat Funk beplan om slegs as hoof- 
redakteur vir die nuwe grammatika op te tree (dan behou dit sy naam, Chicago University Press as uitgewers en veral belangrik, die binding met die Blass/ DeBrunner-grammatika). Die eintlike werk gaan egter deur 'n hele groep jonger kollegas gedoen word. Mense soos Lane C McGaughy (Willarnette University, Oregon), Daryl D Schmidt (Texas Christian University) en Chan-Hie Kim (Claremont School of Theology) sal waarskynlik die werklike samestellers van die nuwe Griekse grammatika wees.

Die bekendste seminaar van die Instituut is egter die Jesus-seminaar, en daaraan word die res van hierdie artikel gewy. Uit wat tot sover gestel is blyk egter duidelik hoe 'n prominente figur Funk is en hoe dinamies en aktief sy instituut oor 'n wye veld optree.

\section{DIE JESUS-SEMINAAR}

\subsection{Doelstellings van die seminaar}

In die openingsrede tydens die eerste vergadering van die seminaar in Maart 1985 in Berkeley, Kalifornië, het Funk (1985a: 1-4) die volgende doelstellings vir die seminaar uitgespel:

- Om te probeer vasstel wat Jesus werklik gesè het: 'Our basic plan is simple. We intend to examine every fragment of the traditions attached to the name of Jesus in order to determine what he really said - not his literal words, perhaps, but the substance and style of his utterances. We are in quest of his voice, insofar as it can be distinguished from many other voices also preserved in the tradition'.

- Om 'n vraag wat gereeld en met aandrang deur studente gevra word, te probeer beantwoord: 'Once our students learn to discern the traditions of the New Testament and other early Christian literature they want to know the ultimate truth: What did Jesus really say? Who was this man to whom the tradition steadily refers itself? For a change, we will be answering a question that is really being asked.'

- Om 'n probleem aan te spreek waarin daar wye en intense belangstelling is en die resultate met die publiek in die algemeen te deel: 'The religious establishment has not allowed the intelligence of high scholarship to pass through pastors and priests to hungry laity, and the radio and TV counterparts of educated clergy have traded in platitudes and pieties and played on the ignorance of the uninformed. A rude and rancorous awakening lies ahead.... 
Our work will spell liberty for millions. Scholars ... have limited their pronoucements to the classroom or buried their considered judgements in scientific journals and technical jargon. They have hesitated to broadcast the assured results of historical critical scholarship (kursivering JB, kyk punt 4 van hierdie artikel) out of fear of public controversy and political reprisal.' Later in sy openingsrede beklemtoon Funk weer hierdie aandrang om die werk 'in full public view' te doen: 'If we are to survive as scholars of the humanities, as well as theologians, we must quit the academic closet.' In die dagblad, Atlanta Joumal and Constitution (Sept 1988), stel hy dit soos volg: 'Heart surgeons and rocket scientists are adept at explaining their work to the public, at writing general interest books and getting interviewed on television. Now its time for the philosophers, theologians and social scientists to do the same.'

'n Groot rede vir die ontstaan van die Jesus-seminaar is dus 'n nuwe besef van die sosiale verantwoordelikheid wat die akademiese gemeenskap teenoor die breë samelewing het (Hollenbach 1989: 13). Dit is dan ook waarom 'n studie van sosiale wetenskappe so 'n groot rol speel in die werk van die Westar Institute.

- Om verdere impak te gee aan die opwindende nuwe era waarin die Bybelwetenskappe tans verkeer en waarin Amerikaners 'n leidende rol speel. Onder 'n nuwe era in veral die Nuwe-Testamentiese wetenskap, noem Funk (i) die beskikbaarheid van nuwe primêre bronne (soos die Evangelie van Thomas, die Dialoog van die Verlosser en die Apokriewe Evangelie van Jakobus); (ii) die beskikbaarheid van nuwe navorsingsinstrumente soos die New Gospel Parallels, die New Sayings Parallels en natuurlik hulpmiddele soos die rekenaar; (iii) die feit dat vroeëre paradigmas in die Bybelwetenskappe, vir baie lank gedomineer deur Duitsers, in die laaste jare suksesvol deur veral Amerikaanse wetenskaplikes deurbreek is: '... we are now moving on to different paradigms: to parables and aphorisms as metaphors and poetry, to narratology, to reader-response criticism, to social description and analysis, and to many other promising ventures.' Funk (1985a: 3) sowel as Hester (1988: 2) is baie trots daarop om te berig dat Europese Bybelwetenskaplikes nou hulle studieverlof in Amerika begin deurbring 'to catch up', en nie meer andersom soos altyd die geval was nie!

Hester (1988: 6-7) druk hierdie aandrang om die isolasie van die resultate van wetenskaplike navorsing in die Bybel te deurbreek in selfs nog sterker terme uit: 
While other disciplines have found the ways and means of sharing with a larger public the findings of their laboratories or longitudinal studies, while the arts have flourished under the protection of freedom of speech and expression, the fruits of biblical scholarship have been tasted primarily by the guild, and the average believer is fed a steady diet of gibberish by those whose knowlegde of how to use modern communications media far exceeds their knowledge of biblical scholarship.

Laasgenoemde is 'n verwysing na die Amerikaanse TV-predikers.

Nog 'n ander prominente lid van Westar, dr Vernon K Robbins van Emory University in Atlanta, stel dit soos volg in 'n berig in die dagblad, The Atlanta Journal and Constitution (Sept 1988): 'The purpose of Westar is to produce materials that will get into the regular bookstores into which adults walk and buy books ... so that some of this scholarly knowledge becomes common knowledge.' Volgens Robbins het ernstige en kwaliteitsnavorsing in die Bybelwetenskappe nie daarin geslaag om onder openbare aandag te kom nie, "because the "right-wing Christian community" (dis nou Graham, Falwell, Bakker, Swaggart en kie) has managed to dominate all talk about religious matters'.

Die basiese doelstelling van die Jesus-seminaar is dus om die resultate van wetenskaplikes wat die 'most faithful question of all, "What did Jesus really say?"', bestudeer (Hester 1988: 7), met die algemene publiek te deel. Hester merk op dat pogings om hierdie werk in die wiele te ry reeds geloods is. Dit is inderdaad 'n riskante onderneming: 'It is as though believers don't want to know!'

\subsection{Werkwyse}

Die lede van die seminaar (wat in Mei 1988 reeds 200 beloop het) vergader twee keer per jaar op verskillende plekke in die VSA. Tydens die eerste vergadering in Berkeley, Kalifornië, gedurende Maart 1985, is daar gepraat oor die beginsels en werkswyse. Met die tweede vergadering in St Meinard, Indiana, is daar besin en gestem oor die saligsprekinge en met die derde byeenkoms in Redlands, Kalifornië, oor enkele van Jesus se gelykenisse (waar onder meer gestem is dat die Teregstellingsgelykenis in die Evangelie van Thomas waarskynlik outentiek is). Tydens die vierde vergadering te Notre Dame is gepraat en gestem oor die apokaliptiese verwagtings wat aan Jesus toegeskryf word. Die byeenkoms in Sonoma was reeds die sewende vergadering. Op die agtste byeenkoms in September 1988 in Atlanta het hulle onder meer tot die gevolgtrekking gekom dat die Ons Vader-gebed (met uitsondering van die woord 'Vader' - Abba) waarskynlik nie oorspronklik van Jesus 
afkomstig is nie, maar moontlik eers jare ná die kruisiging deur 'n groep Christene saamgestel is.

Soos telkens tevore het hierdie byeenkoms hoofopskrifte in die openbare pers gehaal. Die Atlanta Joumal and Constitution stel dit sensasioneel: 'Lord's Prayer not Jesus's, scholars say' - maar Funk het sy sin gekry: die werk van Bybelwetenskaplikes geniet openbare aandag. Tydens hierdie byeenkoms is die Seminaar se Color-coded guide to 33 parables ook gepubliseer, maar daaroor later meer (kyk punt 4 van hierdie artikel).

As databasis vir die besprekings word JD Crossan se boek, Sayings Parallels: $A$ workbook for the Jesus tradition, gebruik. Crossan het die woorde wat in die kanonieke evangelies en in sommige van die belangriker apokriewe evangelies aan Jesus toegeskryf word, in hierdie boek in vier kategoriê gerangskik, naamlik, gelykenisse, aforismes, dialoë en verhale. Crossan identifiseer 503 sulke 'sayings' (of, soos dit vir die doel van hierdie artikel vertaal word, 'Jesuswoorde'). Die seminaar werk dit deur in 'n proses wat vyf tot ses jaar sal neem. Vir elke byeenkoms word spesiale studies oor die Jesuswoorde wat aan die orde is deur lede voorberei en dit word voor die byeenkoms noukeurig bestudeer. Hierdie werkstukke, asook die resultate van die byeenkomste, word periodiek in Westar se vaktydskrif Forum gepubliseer. Tydens die byeenkomste word ure-lange intensiewe besprekings gevoer en die Jesuswoorde word aan die hand van 'n reeks kriteria beoordeel vir outentisiteit. Uiteindelik word daar gestem of Jesus dit wel sou gesè het of nie. Op hierdie wyse hoop die Seminaar om uiteindelik 'n databasis saam te stel om te probeer vasstel wie Jesus werklik was - 'The echo of his voice will define the boundaries of his character' (Hester 1988: 8). Nie minder nie as 150 antieke dokumente - almal ouer as die vierde eeu $\mathrm{nC}$ word deur die Seminaar as basismate riaal gebruik (oor die belangrikheid van taal in hierdie hele onderneming, kyk punt 3.2).

Die stemprosedure werk soos volg (Funk 1985b: 31-32): lede stem in vier kategorië, aangedui deur die kleure rooi, pienk, grys en swart. Hulle doen dit na analogie van die reeds bekende sogenoemde 'rooiletter-uitgawes' van die Bybel waarin al die woorde wat in die Evangelies aan Jesus toegeskryf word in rooi gedruk is en al die res in swart. Die gedagte om kleure vir hierdie doel te gebruik, is dus 'n inspeling van Funk-hulle op 'n bestaande praktyk, maar natuurlik met 'n heel ander en baie meer geraffineerde doel voor oë.

Volgens die Jesus-seminaar se katagorië staan rooi vir woorde wat Jesus beslis sou gesê het, terwyl swart staan vir woorde wat beslis nie van hom af kan wees nie maar wat agterna aan hom toegeskryf is. Pienk is vir woorde wat waarskynlik aan Jesus toegeskryf kan word, of wat iets verteenwoordig soortgelyks aan wat hy sou 
kon gesê het. Of, soos Funk dit stel, 'probability of attribution' of 'congruence in content' word met pienk aangeduị. Die grys kategorie is die mees problematiese. Dit dui Jesuswoorde aan wat waarskynlik, maar nie met sekerheid nie, aan latere tradisies toegeskryf kan word. Grys dui dus twyfel aan oor swart as die gepaste kategorie in die betrokke geval. Die lede stem anoniem deur 'n stemklippie met ' $n$ bepaalde kleur in die stembus te plaas nadat die bepaalde Jesuswoorde bespreek is. Hierdie stemme word dan in 'n ingewikkelde prosedure volgens allerlei statistiese maatstawwe (uitgewerk deur Adam Culpepper en James Hester) deur 'n rekenaar verwerk.

Die plan is om die finale resultate van die seminaar deur Polebridge Press te publiseer onder die titel, The Five Gospels: New red-letter edition. (Dit wil sê, die Evangelie van Thomas word ook ingesluit). In die Desember 1986-uitgawe van Forum is 'n paar voorbeeldbladsye van hierdie boek gepubliseer. Die eerste paar saligsprekinge in Matteus 5 word daarin soos volg geklassifiseer:

Matt 5: 3 'Blessed are the poor in spirit for theirs is the kingdom of heaven.' (Die woorde in spirit is in pienk, die res in rooi).

Matt 5: 4 'Blessed are those who mourn, for they shall be comforted.' (Alles in rooi).

Matt 5:5 'Blessed are the meek, for they shall inherit the earth.' (Alles in swart).

Matt 5: 6 'Blessed are those who hunger and thirst for righteousness, for they shall be satisfied.' (Alles in pienk).

'n Meer volledige voorlopige uitgawe van die resultate van die Jesus-seminaar, $A$ color-coded guide to 33 parables, is tydens die Atlanta-byeenkoms in September 1988 vrygestel. Enkele interessanthede uit hierdie voor-publikasie is dat die gelykenis van die barmhartige Samaritaan (Luk 10) in rooi gedruk is (wat dui op oorweldigende steun vir die keuse dat hierdie gelykenis inderdaad van Jesus afkomstig is). Aan die ander kant is daar met groot meerderheid gestem dat die gelykenis van die landbouer wat die goeie saad van die onkruid skei (Matt 13: 24-30) eers ná die kruisiging ontstaan het. Dit is dus in swart gedruk.

Soos reeds gesê, is hierdie keuses die resultaat van akademiese werk van die hoogste gehalte, gedoen deur van die beste akademici in die Bybelwetenskappe vandag. Dit is dus nie 'n lawwe, willekeurige toekenning van kleure soos dit miskien op die oog af vir'n buitestaander mag lyk nie. 
2.3 Kriteria vir outentisiteit

Dit word algemeen aanvaar dat Jesus se woorde nie onmiddelik verbatim - soos in 'n dagboekverslag - neergeskryf is op die oomblik wat hy dit uitgespreek het nie. Daar het ten minste 'n paar dekades verloop tussen die kruisiging van Jesus en die skrywe van Markus, die oudste Evangelie.

Die studie oor wat met Jesus se woorde gebeur het van die tyd/oomblik toe dit uitgespreek is tot met die verskyning daarvan in vroeg-Christelike tekste, is ingewikkeld en het reeds 'n lang geskiedenis. Boring (1985: 3-4) onderskei vier fases in die studie van hierdie probleem:

(i) die tydperk voor die Aufklärung toe daar feitlik geen bewussyn was van 'n gaping tussen Jesus en dit wat in die tekste nie aan hom toegeskryf word nie,

(ii) die tydperk vanaf die Aufklärung tot die Eerste Wêreldoorlog toe die tekste op 'n objektiverende wyse bestudeer is met die basiese uitgangspunt dat die Jesus van 30 vC en die Jesus van die Christelike tekste nie eenvoudig geïdentifiseer kan word nie. Jesus self en die Jesus van die tekste was die twee pole en op hierdie pole het die studie van die Jesustradisie voor 1918 gefokus.

(iii) Die volgende fase is ingelui en beheers deur Bultmann, Dibelius en Schmidt. In hierdie fase is daar in die eerste plek nie op die twee pole gekonsentreer nie, maar op die gaping self. Die kerugma van die vroeë kerk was primêr in fokus en nie die geskiedenis van Jesus of die verhale van die evangeliste nie. Dit was die era van die hoogbloei van Formgeschichte (vgl McKnight 1969 en Vorster 1983: 97).

(iv) Na die Tweede Wêreldoorlog het die aandag weer terug verskuif na beide die oorspronklike twee pole: aan die een kant die 'New Quest' na die historiese Jesus en aan die ander kant die redaksiekritiek van die Evangelies (vgl Robinson 1959 en Perrin 1970).

Boring self waarsku egter tereg dat hierdie weergawe van die geskiedenis van die studie van die Jesustradisie in baie opsigte oorvereenvoudig is. (Vir 'n duidelike en toeganklike weergawe van hierdie faset van die geskiedenis van die Nuwe-Testamentiese wetenskap, kyk Schnell 1987: 168-184.)

Die resultaat van hierdie ontwikkeling was dat die belangstelling in Jesus nou hoofsaaklik gerig is op sy woorde, soos onder andere blyk uit die hernieude belangstelling in die gelykenisse en in die Jesustradisie as sodanig. Die Amerikaanse Jesus-seminaar kan in 'n sekere sin as die kulminasie van hierdie nuwe belangstelling in die woorde van Jesus gesien word. 
Met inagneming van hierdie lang tradisie in die studie van die probleem van die Jesustradisie, stel Boring (1985: 8-20 - kyk ook hierdie artikel vir die verwysings na die persone wat hier onder genoem word) nege kriteria voor vir die vasstelling van die outentisiteit van woorde wat deur die tradisie aan Jesus toegeskryf word. Die eerste agt neem hy oor by verskeie historiese kritici wat oor die onderwerp geskryf het en die laaste is sy eie voorstel. Hierdie kriteria sluit waarskynlik nie al die kriteria in wat tydens die seminaar in oorweging geneem word nie, maar dit verteenwoordig dié wat algemeen gebruik word. Verder is dit ook belangrik om daarop te wys dat hierdie kriteria voortdurend aangepas en uitgebrei is soos wat die seminaar die afgelope paar jaar gevorder het met hulle werk (vgl Hollenbach 1989: 15-16).

1) Meenoudige voorkoms: as bepaalde Jesuswoorde onafhanklik voorkom in meer as een bron, is dit moontlik van Jesus. Dit is ' $n$ kriterium wat reeds in 1906 deur FC Burkitt voorgestel is.

2) Meenormige voorkoms: indien elemente van die tradisie voorkom in meer as een vorm, is dit moontlik baie vroeg, indien nie van Jesus self nie. Dit is ' $n$ kriterium wat in 1962 deur Nils Dahl voorgestel is.

3) Linguistiese kriterium: indien die styl en idioom van Jesuswoorde noue ooreenkoms toon met Aramees, kan outentisiteit veronderstel word. 'n Kriteria in 1963 voorgestel deur HEC Turner, met natuurlik die invloed van Joachim Jeremias daaragter.

4) Die milieu-kriterium: Jesuswoorde wat die kulturele, politieke en sosiale milieu van Jesus reflekteer kon minder waarskynlik deur die latere hellenistiese kerk geskep gewees het, en is dus meer waarskynlik van Jesus self. Ook 'n kriterium wat aan Jeremias toegeskryf kan word.

5) Tendense in die ontwikkelende tradisie: volgens die ouer vormkritici is dit moontlik om 'wette' te identifiseer waarvolgens 'n later tradisie van 'n vroeë tradisie onderskei kan word. 'n Tradisie word byvoorbeeld langer en meer gedetaileerd hoe langer dit oorgelewer word. In plaas van 'wette', verkies Boring om liewer van 'tendense' in hierdie verband te praat. Dit is dus moontlik dat 'n langer, meer gedetailleerde tradisie later is as 'n kernagtige en spesifiek gerigte een. Dit is ' $n$ kriterium wat veral aan Bultmann toegeskryf kan word en verder ontwikkel is deur EP Sanders.

6) Nie-ooreenstemming (Dissimilarity): indien 'n Jesuswoord nie die idees van Judaisme of die Christendom reflekteer nie, of as dit in kontras is met sowel Judaïsme as die Christendom, kom dit waarskynlik van Jesus. Met ander woorde, dit is meer waarskynlik dat Jesuswoorde wat hierdie tradisies reflekteer 
in Jesus se mond geplaas sou word as wat hy dit self sou gesê het. Dit wil nie noodwendig sê dat elke ding wat Jesus gesê het geheel uniek was nie. Dit sou egter vir die vroeë kerk makliker wees om in sosiale en kulturele kontekste verskillend van die van Jesus, Jesuswoorde te skep waarin hulle gebruik maak van hulle eie tradisies of dié van algemene Judaïsme, as wat dit sou wees om Jesuswoorde van Jesus self te vind wat iemand toevallig sou onthou en oorgelewer het. Dit is dus waarskynlik beter om van 'distinctiveness' as van 'dissimilarity' te praat. Bultmann en JM Robinson word deur Boring aangedui as die vaders van hierdie kriterium (vgl ook Schnell 1987: 182 en veral Hollenbach 1989: 15-16 se meer breedvoerige bespreking van die probleme rondom 'dissimilarity' as kriterium vir die vasstelling van outentieke Jesuswoorde).

7) Modifikasie: wanneer dit moontlik is om aan te dui dat daar variante van 'n tradisie is ('n gevolg van aanpassings/modifikasies), is die meer radikale variant die vroegste. Dit is 'n kriterium wat aan Käsemann toegeskryf kan word.

8) Samehang: wanneer 'n mens 'n 'krities getoetste sekere' minimum (of: 'gewaarborgde minimum') hoeveelheid Jesuswoorde het, kan dit moontlik wees om ander te identifiseer wat ook van hom is indien daar 'n samehang in byvoorbeeld tema en styl daarmee is. ' $n$ Kriterium voorgestel deur Charles Carlston (vgl Schnell 1987: 183).

9) Geloofwaardige tradisiegeskiedenis: as dit moontlik is om 'n geskiedenis van die tradisie te skryf met die oog op die identifisering van die vroegste vorm daarvan, dan is dit ook moontlik om te redeneer dat die geskiedenis self, indien as geheel gesien, die identiteit van die vroegste vorm ondersteun. Met ander woorde, die feit dat 'n mens 'n geskiedenis van 'n tradisie kan vind, ondersteun die outensiteit van die bepaalde Jesuswoorde. Die feit dat 'n tradisie 'n geskiedenis tot gevolg gehad het, toon aan dat die oorspronklike Jesuswoorde 'n hermeneutiese krag gehad het wat dit moontlik gemaak het om soveel verskillende vorms te produseer. Hierdie is Boring se eie voorstel.

Dit is belangrik om daarop te wys dat die historiese kritikus hierdie kriteria in samehang gebruik. Nie een kriterium kan op sigself die gewig dra om te redeneer vir outentisiteit nie. Alle relevante kriteria word in ag geneem en die Jesuswoorde word binne konteks ontleed.

Op hierdie punt het Vernon Robbins (1985) 'n belangrike bydrae tot die seminaar gelewer met sy artikel 'Pragmatic relations as a criterion for authentic sayings'. Hy meen dat Boring se aangepaste vormkritiese metode nie genoegsaam rekening hou met die krag van die konteks waarin die vorms deur die outeur geplaas is nie. Deur die vorms uit konteks te neem en te analiseer binne 'n konteks wat meer 
bevredigende resultate lewer, verloor die vormkritikus die moontlikheid om die bydrae van die konteks tot die betekenis van die Jesuswoord raak te sien. Anders gestel: deur die vorm in 'n konteks te plaas wat deur die kritikus geskep is, neem die Jesuswoorde betekenis binne daardie konteks aan en die eindresultaat is dus 'n ander betekenis. Robbins stel dus kriteria vir pragmatiese relasies voor aan die hand waarvan klusters vorm- en/of retoriese eenhede ontleed moet word. Die seminaar probeer tans om ook sover moontlik hiermee rekening te hou.

\section{DIE RETORIESE SITUASIE VAN DIE JESUS-SEMINAAR}

Die nou reeds bekende definisie van die retoriese situasie deur Bitzer (1968: 6) lui soos volg:

... a complex of persons, events, objects, and relations presenting an actual or potential exigence, which can be completely or partially removed if discourse ... can so constrain human decision as to bring about the significant modification of the exigence.

Hester (1988: 4-6) gebruik hierdie konsep op 'n uiters interessante wyse om die Jesus-seminaar te interpreteer. Volgens hom is die verlies van Scholars Press deur Funk die gebeurtenis wat aanleiding gegee het (die 'exigence') tot die situasies en ontwikkelings wat uigeloop het op die seminaar, wat die diskoersreaksie op die situasie is. Agter hierdie gebeurtenis lê daar egter 'n teoretiese substruktuur wat die seminaar verder verduidelik. Hester noem twee sake in sy bespreking van hierdie teoretiese substruktuur: (i) die mite van die Amerikaanse Weste en (ii) die krag van taal.

\subsection{Die mite van die Weste}

Die krag en uitwerking van hierdie mite in die bestaan en werking van die Jesusseminaar, Westar Institue en Polebridge Press kan nouliks oorskat word. Funk noem byvoorbeeld die uitgewery wat hy as opvolger (of miskien liewer: in die plek van?) Scholars Press tot stand gebring het, Polebridge Press. Polebridge is 'n klein dorpie met minder as 100 inwoners in noord-Montana, naby Glacier National Park. Funk self het vir baie jare in Montana gewoon. Die naam Polebridge is an identifiable American symbol. It envokes the American West, the unsettled frontier, the place to which one goes for new vistas. On the way west, one should travel light, respect his environment and, out of nesessity, put inappropriate habits behind' (White 1987: 7). Met ander woorde, die weste is die archetipiese simbool van 'n 
plek van hoop en belofte, 'despite the grim realities of long journeys across trackless prairie and over rugged mountain passes' (Hester 1988: 4). Die visie van die pelgrim is gebaseer op die potensiële krag van nuwe hemel en nuwe aarde-mites wat nuwe realiteite skep, en die konkrete ervarings (en swaarkry) van die pelgrim kan dit nie volledig omvat nie. Volgens Hester (1988) is Funk 'n direkte geestelike erfgenaam van Jonathan Edwards en die ander evangeliste van die 'Great Awakening'. Hulle visie van ' $n$ uitstorting van die Gees in Amerika het hulle daartoe gebring om, ten spyte van die geestelike en morele verval in Europa, vas te hou aan en aan te dring op die geldigheid van die Amerikaanse godsdiens en die hoop wat daarin vervat is. Ook hierdie evangeliste het in die weste geleef en gewerk.

Polebridge Press en Westar Institute wil dus pioniers wees. Hulle wil nuwe paaie in die wetenskap verken, nuwe realiteite skep en 'n eg Amerikaanse impuls gee aan die studie van die Bybel en van godsdiens. Simbole soos 'The Farmer', 'The Mountainman' en 'The Cowboy' word op die voorblad van die tydskrif Forum gebruik - hulle is die soort mense wat nuwe realiteite skep in situasies waar die 'establishment' lewe nie moontlik ag nie. Let ook op die metaforiese krag van die naam Westar: die blink nuwe ster in die weste wat nuuskierig (en met afguns?!) in die ooste gesien sal word. Die 'ooste' is natuurlik die 'establishment' aan die Ooskus van die VSA, en nog verder oos, die ou en stagnante Europa!

\subsection{Die krag van taal}

As kind van die voorposte en as Protestant het Funk reeds vroeg die krag van taal ingesien. Dit is versterk deurdat hy sy akademiese loopbaan in die era van Fuchs en Ebeling se 'New Hermeneutic' begin het. Reeds in 1961 vertaal hy Blass en DeBrunner se Griekse grammatika en in 1972 verskyn sy eie Griekse grammatikahandboek. Hy is steeds op uitgebreide skaal besig met vertaalwerk (bv die Hermeneiakommentaarreeks). Met die publikasie van Language, hermeneutics and word of God in 1966 het hy 'n baie belangrike bydrae tot die Bybelwetenskap gelewer. In die voorwoord van hierdie boek skryf hy:

Our history - the history we seek to lay bare - is transmitted in the form of language. It is therefore the linguistic tradition that both bears and conceals our disposition to history and reality... What we can see is presided over by what we can say.... Language does not merely stand at our beck and call; it is there before we are, it situates us, restricts our horizon, it refuses us its total complicity.... The first task is to expose the roots of our linguistic tradition and the second, 
which is wholly concomitant, is to liberate language from the hegemony of prescriptive thought (Funk 1966: xii, xiii).

Hierdie beskouing van taal geniet vandag wye erkenning.

Om die verskil tussen hierdie en ander taalopvattings te verduidelik, onderskei Swanepoel (1986: 302-303) tussen die taalbeskouing wat die aard van benoeming sien as benoeming as ' $n$ inventaris (of: taal as nomenklatuur) en benoeming as ' $n$ sisteem (of: benoeming as iets differensieels). In die begin van hierdie eeu het Ferdinand de Saussure al die idee dat taal in sy wese nomenklatuur is, dit wil sê, 'n lys terme wat ooreenstem met 'n gelyke aantal 'dinge', in twyfel getrek. Woorde is nie maar net etikette wat die taalgebruiker aan verskynsels in die werklikheid toeken nie. Reeds die feit dat verskillende tale verskillende klankkombinasies (of woorde) gebruik om na dieselfde verskynsels te verwys, toon die onhoudbaarheid van so 'n standpunt. Die probleem gaan egter veel dieper: verskillende kulture het verskillende opvattings oor verskynsels wat op die oog af dieselfde blyk te wees. 'n Mens sou kon vra: bestaan daar so iets soos 'skuld' in die 'objektiewe werklikheid' en is verskillende kulture se opvattings oor 'skuld' presies dieselfde? Vergelykende ondersoek toon dat dit nie die geval is nie. Dit is dus nie maar net een en dieselfde 'ding' wat bloot in verskillende tale verskillende etikette het nie.

In teenstelling met hierdie opvatting, bestaan daar baie lank reeds in die taalkunde die opvatting dat taal die gebruiker daarvan se denke lei. Taal segmenteer die werklikheid op 'n manier wat eie aan hom is en hierdie segmenterings of 'snitte' verskil van taal tot taal. Swanepoel (1986: 303) toon aan dat hierdie opvatting (benoeming as icts differensieels) reeds ver teruggaan. Lank voor Sapir en Whorf in hierdie eeu, het $W$ von Humboldt taal reeds in die negentiende eeu gesien as ' $n$ aktiewe beginsel wat ' $n$ vaste stel onderskeidende waardes op die denke afdwing. Die besondere taalsisteem bied aan sy gebruikers 'n prisma waardeur hy die nie-linguistiese sisteem beskou. Taal is dus nie bloot 'n 'bag of words' wat taalgebruikers aanwend om sake te etiketteer nie. Taal skep die mens se opvatting en begrip van die sogenaamde 'objektiewe werklikheid' (Swanepoel 1986: 304).

Hoewel Funk dus nie die eerste persoon is wat hierdie taalbeskouing huldig nie, was hy van die eerstes om dit van toepassing te maak op die studie van die Bybel. Hierdie inset van hom is steeds nog besig om sy invloed in die Nuwe-Testamentiese wetenskap te laat geld, soos onder andere blyk uit latere navorsing op die gelykenisse (kyk Via 1967, Funk 1982) en selfs ook die Nuwe-Testamentiese briewe (kyk Stowers 1986: 24-25).

Die twintigste-eeuse Nuwe-Testamentiese wetenskap het grootliks die pogings laat vaar om 'n biografie van Jesus te skryf. Dit was die mikpunt van die oor- 
spronklike 'Quest for the historical Jesus' - die naam deur vertalers gegee aan Albert Schweitzer se beskrywing van pogings van die liberale teologie om sodanige biografie te skryf. Dit het geblyk dat gegewens oor Jesus in die Evangelies sodanig oordek is met die kerk se belydenis van Jesus as Here, dat dit nie moontlik is om veel oor die historiese Jesus te sê nie. Vormkritici het egter die moontlikheid geopper dat die historiese Jesus gevind kan word deur die identifisering van sy woorde.

Dit is hier waar Funk se gedagte van die krag van taal as skepper van realiteit in die prentjie kom. Met mense soos Bultmann, Heidegger, Owen Barfield en Maurice Merleau-Ponti as sy intellektuele vaders agter hom, kyk Funk saam met ander historiese kritici af in die put van die geskiedenis. Maar in plaas daarvan om die gesig van Jesus te sien reflekteer op die bodem, hoor Funk die eggo van Jesus se stem (Hester 1988: 6). Die historiese Jesus kan gevind word in taal, wat natuurlik altyd geinterpreteer moet word indien daar aanspraak op realiteit gemaak wil word. Deur hermeneutiek kan Jesus dus ons geskiedenis en ons realiteit binnetree. Wanneer ons gekonfronteer word met Jesus se táal, word ons met hóm gekonfronteer. In hierdie konfrontasie is dit dus nie meer belangrik om die detail van sy historiese bestaan te weet nie, maar om sy taalwêreld binne te tree. Want deur sy taal, skep hy realiteit.

Die invloed van Funk se intellektuele vaders (en veral ook die Nuwe Hermeneutiek van Fuchs en Ebeling) is duidelik merkbaar in hierdie siening. Die bepaalde taalbeskouing wat Funk huldig, verduidelik dus die motivering van die Jesusseminaar om die outentieke woorde (of die taal) van Jesus vas te stel, en die gedagte om op grond van so 'n databasis, die karakter van Jesus te beskryf.

\section{DIE 'NUWE ROOILETTER JESUS', DIE NUWE-TESTAMENTIESE WETENSKAP EN DIE KERK}

Een van die basiese opvattings van die Vormkritiek is dat die Jesuswoorde (met die uitsondering van die lydensverhaal), grotendeels as mondelinge fragmente in die vroeg-Christelike gemeenskappe gesirkuleer het. Die vorms van hierdie tradisies en tot ' $n$ mindere of meerdere mate ook die inhoud daarvan, is bepaal deur die situasies in die lewe van die vroeë kerk (die Sitz im Leben) waarin dit gebruik is. Hierdie vorms is later deur die evangelieskrywers oorgeneem en in 'n narratiewe patroon ingevoeg (vgl Vorster 1983: 98-99). Die reaksie van die Redaksiekritiek hierop was dat die outeurs van die Evangelies nie eenvoudig as versamelaars en redakteurs gesien moet word nie, maar dat hulle 'n aktiewe rol gespeel het in vormgewing en skepping van die materiaal wat hulle gekies het om hulle verhale te vertel (vgl 
Perrin 1970: 25-33, Vorster 1983: 107). Met ander woorde, die mondelinge tradisie het oorgegaan in 'n literêre tradisie en in so 'n geval kan van die invloed van die skrywers van die literêre tradisie nie ontkom word nie. Daar kan dus nie sonder meer aangeneem word dat selfs die mees noukeurige analise die woorde van die oorspronklike spreker sal blootlê nie.

Maar selfs al sou ons die woorde van die oorspronklike spreker hê, kan ons ook nog nie sonder meer aanneem dat ons daardeur direkte toegang tot die betekenis van die woorde het nie. Sonder kennis van die oorspronklike gehoor en die situasie wat aanleiding gegee het tot die uitspreek van die betrokke woorde, kan die oorspronklike betekenis van die betrokke woorde moeilik vasgestel word. Hester (1988: 11) kom dus na my oordeel tot 'n geldige beoordeling: 'Identifying the voice of Jesus is not going to bring us into full and direct knowledge of him'. Tog maak Funk 'n punt wat ons aandag werd is as hy sê dat die taal van Jesus ons sy leefwêreld binnenooi en dat ons deur taal met die boodskap van Jesus gekonfronteer word. Aan die ander kant is dit na my oortuiging tog dadelik ook nodig om hierdie moontlike oordrewe vertroue in taal (of dan die literêre aard van die Bybel), te relativeer. Dit is ook te betwyfel of die lede van die seminaar werklik glo dat konsensus oor wat Jesus gesê het, waarlik volle kennis oor Jesus self aan ons sal gee. Tog is daar die moontlikheid dat die kritiese werk van hierdie seminaar ons in sekere opsigte nader kan bring aan Jesus en hoe hy homself gesien het.

Een van die hoofredes vir die ontstaan van die seminaar, naamlik om die wetenskaplike werk van Bybelwetenskaplikes onder die aandag van die kerkvolk en die publiek in die algemeen te bring, is myns insiens ' $n$ uiters positiewe ideaal. Tydens die 1988-kongres van die Nuwe-Testamentiese Werkgemeenskap van Suid-Afrika (NTWSA) is hierdie belangrike saak ook spesifiek deur Smit (1988) aangeroer. Ná 'n hele reeks opmerkings oor wat die doel van die interpretasie (deur die 'interpretive community') van die Bybel kan en behoort te wees, skryf Smit (1988: 475) dat dit vandag die oortuiging van 'n groot deel van die Christelike gemeenskap is dat die doel van interpretasie moet wees om die letterlike en historiese betekenis van die Bybel te verstaan. Hierdie oortuiging kan toegeskryf word aan bepaalde sosio-historiese veranderinge oor die laaste paar eeue in die Westerse samelewing. Smit (1988: 475) stel dit as sy oortuiging dat die Nuwe-Testamentiese wetenskap spesifiek die taak het om die kerk te konfronteer met die konsekwensies van die gelowige Christelike gemeenskap se tradisionele opvattings oor die historiese en literère aard van die Bybel. Hy meen dat nòg die historiese nòg die literêre 'quest' ten opsigte van die Bybel werklik in die wetenskap ernstig opgeneem word. Wanneer die Nuwe-Testamentiese wetenskap dit doen en dit duidelik onder die Christelike gemeenskap se aandag bring, mag dit moontlik deur hierdie gemeenskap as 'n 
ondiens ervaar word. Dit sou egter die resultaat daarvan wees dat die kerk onbewus is van die konsekwensies van haar eie aansprake ten opsigte van die Bybel. Smit (1988: 475) eindig hierdie deel van sy argument met die volgende uiters belangrike stellings:

In fact, if postmodernism is the awareness that confidence in both history and language has been mistakenly placed, that they are both disseminating, not unifying forces, and that both lead to irreversible pluralities and ambiguities, scholarship which becomes aware of this should warn the believing community of the fundamental problems involved in their very aim, and in their trust in the historical and literary quests of interpretation.

The service rendered to the church by the social project of New Testament scholarship may, at a particular point in time, therefore consist of ongoing tension, of criticism, and of struggle (Tracy 1987).

Die belangrikheid daarvan om die resultate van die Bybelwetenskap onder die kerkvolk (en die algemene publiek) se aandag te bring, word dus hier treffend deur Smit onderskryf en verder gemotiveer. Terselfdertyd bring hy ook met hierdie redenasie van hom geldige kritiek teen sommige van die basiese opvattings van die Jesusseminaar in, veral dan ten opsigte van hulle moontlike oordrewe vertroue in die krag en moontlikhede van taal. Funk se moontlike oordrewe vertroue in die historiese paradigma blyk ook duidelik uit die feit dat hy in 1985 nog van die 'assured results of historical critical scholarship' (kyk punt 2.1.3) praat. Daar is in die afgelope klompie jare eenvoudig net te veel geldige kritiek teen hierdie paradigma ingebring om nog so ongenuanseerd vertroue daarin te kan hê (vgl bv Vorster 1984 en Nations 1983). Ten opsigte van die wyse walarop hulle hulle vertroue in taal en in die geskiedenis stel, kan daar dus geldige kritiek teen die Jesus-seminaar ingebring word. Dit wil egter hoegenaamd nie sê dat die hele saak as sodanig daarmee maar van die tafel af gevee kan word nie.

Baie beelde, name en voorstellings van Jesus het in die loop van die kerkgeskiedenis gekom en gegaan (kyk Gascoigne 1977). Almal het op een of ander wyse die kulturele en politieke omstandighede van die kerk van die tyd gereflekteer. So was daar die Jesus in die puperkleed van die Bisantynse Vors in die vierde eeu, die fanatieke Jesus op ' $n$ perd met die swaard in die hand van die tiende-eeuse kruistogte, die Jesus van die negentiende-eeuse Liberale Teologie en meer resent, Jesus as latyns-Amerkaanse vryheidsvegter met 'n AK 47 in die hand. Hoe gaan die 'nuwe rooiletter Jesus', die Jesus van 'n deel van die laat twintigste-eeuse Ameri- 
kaanse akademiese gilde lyk? Dit sal slegs die tyd ons kan leer. Hierdie keer sal ons dit ook nog in 'n film sien. Die filmregisseur, Paul Vanhoeven van Hollywood (onder meer bekend as regisseur van Robocop en Soldier of Orange), het spesiaal die Sonoma-kongres bygewoon om te onderhandel vir die regte om 'n film van die 'nuwe rooiletter Jesus' te maak.

Jesus self het al die vraag gevra (die seminaar het nog nie besluit of dit 'n rooi, pienk, grys of swart vraag is nie!): 'Wie, sê die mense is Ek?' (Mark 8: 27). Die Christelike tradisie het geantwoord: Die Christus, die Opgestane, Verheerlikte Here wat aan die regterhand van God die Vader sit en weer sal kom om die lewendes en die dooies te oordeel.

Om hierdie antwoord verder in te vul en nuwe inhoud en betekenis vir ons tyd te gee, vra die Jesus-seminaar nou: Wat van die man van Nasaret, die man wat met soveel krag gepreek en geleer het dat die wêreld ná hom nooit weer dieselfde was nie? Die antwoord op hierdie vraag mag riskant wees. Bekende en geliefde voorstellings van Jesus mag in die slag bly. Daar kan tereg in hierdie verband van ' $n$ 'spanning' en 'n 'kritiek' en 'n 'stryd' gepraat word (kyk die opmerking van Smit hierbo). Tog mag dit ook bevrydend en verdiepend inwerk op die kerk. Daar is genoegsame positiewe motiewe en verantwoorde metodologiese uitgangspunte en bekwame Bybelwetenskaplikes aan die Jesus-seminaar verbind om die verdere verloop van die saak met meer as terloopse aandag te volg. Hollenbach (1989: 20) gaan so ver as om hierdie nuwe 'quest' na die historiese Jesus 'n 'profetiese aktiwiteit' te noem - veral omdat daar in die die VSA na sy oordeel blatante ideologiese regverdiging vir politieke en ekonomiese imperialisme, mishandeling en moord gevind word in sekere tradisionele interpretasies van die sosiale rol van die Christendom.

\section{Literatuurverwysings}

BELL, TD 1987. Will the REAL Jesus please stand up? Westar Magazine 1: 9-11.

BITZER, LF 1968. The rhetorical situation. Philosophy and rhetoric 1: 1-24.

BORING, ME 1985. Criteria for authenticity: The Lucan beatitudes as a test case. Foundations and Facets forum 1/4, 3-38.

FUNK, RW 1966. Langhage, hermeneutic and word of God. New York: Ilarper and Row.

FUNK, RW 1985a. The issue of Jesus. Foundations and facets forum 1/1, 1-6.

FUNK, RW 1985b. Polling the pundits. Foundations and facets forum 1/1, 31-50.

GASCOIGNE, B 1977. The Christians. London: Jonathan Cape. 
HENDRICKS, HJ 1988. Tendense in die Amerikaanse kerklike situasie en die moontlike implikasies daarvan vir die kerk in SA. NGTT 29/1,41-54.

HENRICK, CW 1985. The Jesus Seminar. A pronouncement. Foundations and facets forum $1 / 3,33-34$.

HESTER, JD 1988. In quest of the rhetorical Jesus: A review of recent journeys. (Ongepubliseerde referaat gelewer tydens ' $n$ fakulteitsbyeenkoms by die University of Redlands, Redlands, Kalifornië.)

HOLLENBACH, P 1989. The historical Jesus question in North America today. Biblical Theology Bulletin 19/1: 10-22.

McKNIGHT, EV 1969. What is fonn criticism? Philadelphia: Fortress.

NATIONS, A 1983. Historical criticism and the current methodological crisis. $S J T /$ 36: 59-71.

OLIVIER, J 1988. Wie was Jesus? Insig Oktober 1988: 24-26.

OSTLING, RN 1988. Who was Jesus? The debate among scholars is as heated as the one in Hollywood. Time nr 38, 15 Augustus 1988: 69-74.

PERRIN, N 1970. What is redaction Criticism? London: SPCK.

ROBBINS, VK 1985. Pragmatic relations as a criterion for authentic sayings. Foundations and facets forum 1/3, 35-63.

ROBINSON, JM 1959. A new quest of the historical Jesus. London: SCM.

SCHNELL, CW 1987. Sosiologies-historiese interpretasie van Markus en Johannes, in De Klerk, JC \& Schnell, CW, Jesus deur ander ö̈: Literêre en sosiologies. historiese interpretasies van Markus en Johannes. Pretoria: Van Schaik.

SMIT, DJ 1988. Responsible hermeneutics: A systematic theologian's response to the readings and readers of Luke 12: 35-48. Neotestamentica 22, 441-484.

STOWERS, S 1986. Letter-writing in Greco-Roman Antiquity. Philadelphia: Westminster.

SWANEPOEL, J 1986. Literêre analise van die Nuwe Testament. Koers 51/3, 287. 327.

VIA, DO 1967. The Parables. Philadelphia: Fortress.

VORSTER, WS 1983. 'Formgeschichte' en 'Redaktionsgeschichte', in Klijn, AFJ (red), Inleiding tot de studie van het Nieuwe Testament. Kampen: Kok.

VORSTER, WS 1984. The historical paradigm - Its possibilities and limitations. Neotestamentica 18, 104-123.

WHITE, JL 1987. The tale of Polebridge Press. Westar Magazine 1/3, 6-7. 